\title{
Classification of thermophilic streptomycetes, including the description of Streptomyces thermoalcalitolerans sp. nov.
}

\author{
Bongcheol Kim, ${ }^{1,2}$ Nevzat Sahin, ${ }^{2} \dagger$ David E. Minnikin, ${ }^{3}$ \\ Jolanta Zakrzewska-Czerwinska, ${ }^{4}$ Marian Mordarski ${ }^{4}$ \\ and Michael Goodfellow ${ }^{1,2}$
}

1,2,3 Departments of Agricultural and Environmental Science', Microbiology ${ }^{2}$ and Chemistry ${ }^{3}$, University of Newcastle, Newcastle upon Tyne NE1 7RU, UK

${ }^{4}$ Institute of Immunology and Experimental Therapy, Polish Academy of Sciences, Czerska 12, 53-114 Wroclaw, Poland
Author for correspondence: Michael Goodfellow. Tel : +44 191222 7706. Fax: +44 1912225228. e-mail:m.goodfellow@ncl.ac.uk

\begin{abstract}
A polyphasic taxonomic study was undertaken to clarify relationships within and between representative thermophilic alkalitolerant streptomycetes isolated from soil and appropriate marker strains. The resultant data, notably those from DNA-DNA relatedness studies, support the taxonomic integrity of the validly described species Streptomyces thermodiastaticus, Streptomyces thermoviolaceus and Streptomyces thermovulgaris. However, the genotypic and phenotypic data clearly show that Streptomyces thermonitrificans Desai and Dhala 1967 and S. thermovulgaris (Henssen 1957) Goodfellow et al. 1987 represent a single species. On the basis of priority, $S$. thermonitrificans is a later subjective synonym of $S$. thermovulgaris. Similarly, 10 out of the 11 representative thermophilic alkalitolerant isolates had a combination of properties consistent with their classification as 5 . thermovu/garis. The remaining thermophilic alkalitolerant isolate, Streptomyces strain TA56, merited species status. The name Streptomyces thermoalcalitolerans sp. nov. is proposed for this strain. A neutrophilic thermophilic isolate, Streptomyces strain NAR85, was identified as $S$. thermodiastaticus.
\end{abstract}

Keywords: classification, thermophilic streptomycetes, Streptomyces thermoalcalitolerans sp. nov.

\section{INTRODUCTION}

Systematic studies on the genus Streptomyces are complex due to the remarkable taxonomic variation encompassed by this taxon and the absence of recognized minimal standards for the circumscription of new species (Manfio et al., 1995; Hain et al., 1997). Nevertheless, it is now clear that established and putatively novel streptomycete species need to be based on a judicious selection of genotypic and phenotypic features (Chun et al., 1997; Hatano et al., 1997; Labeda et al., 1997). Molecular systematic data are proving to be especially useful in determining the boundaries and internal taxonomic structure of the genus (Labeda, 1993, 1996; Kim et al., 1996, 1998; Labeda et al., 1997).

Thermophilic streptomycetes grow between 25 and $55^{\circ} \mathrm{C}$. These organisms, which grow quite well at

†Present address : OMÜ Egitim Fakültesi, Biyoloji Bölümü, 55200 AtakumSamsun, Turkey.
$50{ }^{\circ} \mathrm{C}$, have been sharply distinguished from mesophilic streptomycetes in numerical phenetic surveys (Goodfellow et al., 1987; O'Donnell et al., 1993); they also fall into several distinct evolutionary clades based on 16S rDNA sequence data (Kim et al., 1996, 1998). It is, therefore, apparent that thermophilic streptomycetes form a diverse group and should not be recognized as a single sub-group within the genus Streptomyces as was proposed by Craveri \& Pagani (1962).

Streptomyces macrosporus Goodfellow et al. 1987, Streptomyces megasporus (Krassilnikov et al. 1968) Agre 1983, Streptomyces thermoautotrophicus Gadkari et al. 1990, Streptomyces thermocarboxydovorans Kim et al. 1998, Streptomyces thermocarboxydus Kim et al. 1998, Streptomyces thermodiastaticus (Bergey et al. 1923) Waksman 1953, Streptomyces thermolineatus Goodfellow et al. 1987, Streptomyces thermonitrificans Desai and Dhala 1967, Streptomyces thermoviolaceus (Henssen 1957) emend. Goodfellow et al., 1987 and Streptomyces thermovulgaris (Henssen 1957) emend. 
Table 1. Test strains

ATCC, American Type Culture Collection, Rockville, MD, USA; CUB, Culture Collection of the University of Bradford, Bradford, UK; DSM, Deutsche Sammlung von Mikroorganismen und Zellkulturen, Braunschweig, Germany; ISP, International Streptomyces Project; NCIM, National Collection of Industrial Microorganisms, Poona, India.

\begin{tabular}{|c|c|c|}
\hline Strain number & Species or subspecies & Strain history \\
\hline \multicolumn{3}{|l|}{ Marker strains } \\
\hline DSM $40443^{\mathrm{T}}$ & $\begin{array}{l}\text { S. thermoviolaceus } \\
\text { subsp. thermoviolaceus }\end{array}$ & $\begin{array}{l}\text { ISP } 5443^{\mathrm{T}} \leftarrow \text { ATCC } 19283^{\mathrm{T}} \leftarrow \text { A. Henssen } ; \mathrm{R}_{77^{\mathrm{T}}}, \\
\text { mixed fresh horse and swine manure }\end{array}$ \\
\hline DSM $40444^{\mathrm{T}}$ & S. thermovulgaris & $\begin{array}{l}\text { ISP } 5444^{\mathrm{T}} \leftarrow \text { ATCC } 19284^{\mathrm{T}} \leftarrow \text { A. Henssen; } \mathrm{R}_{10}{ }^{\mathrm{T}} \text {, } \\
\text { cow manure }\end{array}$ \\
\hline DSM $40573^{T}$ & S. thermodiastaticus & ISP $5573^{\mathrm{T}} \leftarrow$ T. Cross, CUB $687 \leftarrow$ J. R. Denison \\
\hline DSM $40579^{\mathrm{T}}$ & S. thermonitrificans & $\begin{array}{l}\text { ISP } 5579^{\mathrm{T}} \leftarrow \text { NCIM } 2007^{\mathrm{T}} \leftarrow \text { A. J. Desai \& S. A. } \\
\text { Dhala; soil, Bombay, India }\end{array}$ \\
\hline DSM $41392^{\mathrm{T}}$ & $\begin{array}{l}\text { S. thermoviolaceus } \\
\text { subsp. apingens }\end{array}$ & ATCC $19994^{T} \leftarrow$ A. Henssen, $R_{89^{T}}$ \\
\hline ISP $5236^{\mathrm{T}}$ & S. griseus & $\begin{array}{l}\text { H. J. Kutzner, Technische Hochschule, } \\
\text { Darmstadt, Germany, DSM } 40236^{T}\end{array}$ \\
\hline \multicolumn{3}{|c|}{ Thermophilic alkalitolerant isolates* } \\
\hline A1853 & Streptomyces sp. & $\begin{array}{l}\text { J. Lacey, Rothamsted Experimental Station, } \\
\text { Harpenden, England, UK; barley grain }\end{array}$ \\
\hline A1956 & Streptomyces sp. & $\begin{array}{l}\text { J. Lacey Rothamsted Experimental Station, } \\
\text { Harpenden, England, UK; barley grain }\end{array}$ \\
\hline NT218 & Streptomyces sp. & N. Sahin; scrubland, Merida, Venezuela \\
\hline $\begin{array}{l}\text { TA12, TA26, } \\
\text { TA56, TA61, } \\
\text { TA123, TA179, } \\
\text { TA265 }\end{array}$ & Streptomyces sp. & N. Sahin; garden soil, Yogyakarta, Indonesia \\
\hline \multicolumn{3}{|c|}{ Thermophilic neutrophilic isolate* } \\
\hline NAR85 & Streptomyces sp. & $\begin{array}{l}\text { A. T. Bull, Department of Biosciences, } \\
\text { University of Canterbury, Kent, UK; lime soil }\end{array}$ \\
\hline
\end{tabular}

* Strains included in the chemosystematic and 16S rDNA sequencing studies.

Goodfellow et al., 1987 are validly described species which contain thermophilic streptomycetes. Additional thermophilic streptomycetes have been assigned to taxa which are not cited in the Approved Lists of Bacterial Names, notably 'Streptomyces thermoflavus' (Kudrina and Maximova 1963) Pridham 1970, 'Streptomyces thermophilus' (Gilbert 1904) Waksman and Henrici 1948 (syn. Streptomyces rectus Henssen 1957) and the illegitimately described 'Streptomyces thermotolerans'. Several investigators have called for comparative taxonomic studies to clarify the finer taxonomic relationships between $S$. thermodiastaticus, $S$. thermonitrificans, $S$. thermoviolaceus and $S$. thermovulgaris (Goodfellow et al., 1987; Kim et al., 1996).

Sahin (1995) isolated large numbers of thermophilic streptomycetes from soil by incubating starch casein agar plates supplemented with cycloheximide and rifampicin, and adjusted to $\mathrm{pH} 10 \cdot 5$, at $55^{\circ} \mathrm{C}$ for $5 \mathrm{~d}$. In a comprehensive numerical phenetic survey of these organisms, representative isolates, which grew between $\mathrm{pH} 6$ and 11.5, formed a distinct aggregate taxon. Marker strains of $S$. thermovulgaris, including the type strain, formed a distinct and homogeneous taxospecies within this aggregrate taxon. Additional marker strains, such as the type strains of $S$. macrosporus, $S$. megasporus, $S$. thermodiastaticus, $S$. thermolineatus and $S$. thermoviolaceus were assigned to other aggregate taxa.

The primary aims of the present investigation were to determine relationships between representative thermophilic alkalitolerant isolates and appropriate marker strains using molecular systematic and microbiological techniques and to clarify relationships between members of established taxa, notably between $S$. thermodiastaticus, $S$. thermonitrificans, $S$. thermoviolaceus and $S$. thermovulgaris.

\section{METHODS}

Organisms and culture conditions. The strains (Table 1), which were maintained on inorganic salt-starch agar (ISP medium 4, Difco; Shirling \& Gottlieb, 1966) at $45^{\circ} \mathrm{C}$ and as glycerol suspensions $(20 \%, \mathrm{v} / \mathrm{v})$ at $-20^{\circ} \mathrm{C}$, were cultivated at $45^{\circ} \mathrm{C}$, unless otherwise stated; they all grow well at this 
Table 2. Strains used and their nucleotide sequence accession numbers

\begin{tabular}{|c|c|c|c|}
\hline Species or subspecies & Strain* & Source ${ }^{\dagger}$ & Accession no. \\
\hline S. abikoensis & & DSM $40831^{\mathrm{T}}$ & $\mathrm{X} 53168$ \\
\hline S. acidiscabies & & ATCC $49003^{\mathrm{T}}$ & D63865 \\
\hline S. albus & ISP $5313^{T}$ & DSM $40313^{T}$ & X53163 \\
\hline S. ambofaciens & ISP $5053^{\mathrm{T}}$ & ATCC $23877^{\mathrm{T}}$ & M27245 \\
\hline S. bikiniensis & ISP $5581^{\mathrm{T}}$ & DSM $40581^{\mathrm{T}}$ & X79851 \\
\hline S. bluensis & ISP $5564^{T}$ & & $\times 79324$ \\
\hline S. bottropensis & ISP $5262^{\mathrm{T}}$ & ATCC $25435^{\mathrm{T}}$ & D63868 \\
\hline S. brasiliensis & & DSM $43159^{T}$ & X53162 \\
\hline S. caelestis & ISP $5084^{T}$ & NRRL $2418^{T}$ & X80824 \\
\hline $\begin{array}{l}\text { S. cinnamoneus subsp. } \\
\text { cinnamoneus }\end{array}$ & ISP $5005^{\mathrm{T}}$ & DPDU $0093^{\mathrm{T}}$ & $\mathrm{X} 53171$ \\
\hline S. diastaticus subsp. diastaticus & ISP $5496^{\mathrm{T}}$ & DSM $40496^{\mathbf{T}}$ & X53161 \\
\hline$S$. diastatochromogenes & ISP $5449^{\mathrm{T}}$ & ATCC $12309^{\mathrm{T}}$ & D63867 \\
\hline 'S. espinosus' & & NRRL 5729 & X80826 \\
\hline S. eurythermus & ISP $5014^{\mathrm{T}}$ & ATCC $14975^{\mathrm{T}}$ & D63870 \\
\hline S. galbus & ISP $5089^{T}$ & DSM $40089^{\mathrm{T}}$ & X79852 \\
\hline S. glaucescens & & DSM 40716 & X79322 \\
\hline S. griseocarneus & ISP $5004^{\mathrm{T}}$ & DSM $40004^{T}$ & X99943 \\
\hline S. griseus & ISP $5236^{\mathrm{T}}$ & KCTC $9080^{\mathrm{T}}$ & $\mathrm{X} 61478$ \\
\hline S. lincolnensis & ISP $5355^{\mathrm{T}}$ & NRRL $2936^{\mathrm{T}}$ & X79854 \\
\hline S. macrosporus & & DSM $41449^{\mathrm{T}}$ & Z68099 \\
\hline S. mashuense & ISP $5221^{\mathrm{T}}$ & DSM $40221^{T}$ & $\times 79323$ \\
\hline S. megasporus & & DSM $41476^{T}$ & Z68100 \\
\hline S. mobaraensis & ISP 5587 & DSM 40587 & X53167 \\
\hline S. neyagawaensis & ISP $5588^{\mathrm{T}}$ & ATCC $27449^{\mathrm{T}}$ & D63869 \\
\hline S. olivoreticuli subsp. cellulophilus & & DPDU $0278^{\mathrm{T}}$ & X53166 \\
\hline S. pseudogriseolus & & NRRL 3985 & X80827 \\
\hline S. purpureus & & DSM $43460^{T}$ & $\mathrm{X} 53170$ \\
\hline S. rimosus & R6-554 & & X62884 \\
\hline S. roseoverticillatus & & DPDU 0819 & X53164 \\
\hline S. salmonis & & DPDU $0098^{\mathrm{T}}$ & $\times 53169$ \\
\hline S. sampsonii & ISP $5394^{\mathrm{T}}$ & ATCC $25495^{\mathrm{T}}$ & D63871 \\
\hline S. scabiei & & ATCC $49173^{T}$ & D63862 \\
\hline S. seoulensis & & IMSNU $21266^{\mathrm{T}}$ & $\mathrm{Z} 71365$ \\
\hline S. setonii & & ATCC $25497^{\mathrm{T}}$ & D63872 \\
\hline S. subrutilus & ISP $5445^{\mathrm{T}}$ & DSM $40445^{\mathrm{T}}$ & $\mathrm{X} 80825$ \\
\hline S. tendae & ISP $5101^{\mathrm{T}}$ & ATCC $19812^{\mathrm{T}}$ & D63873 \\
\hline S. thermocarboxydovorans & $\operatorname{AT} 52^{\mathrm{T}}$ & DSM $44296^{\mathrm{T}}$ & U94489 \\
\hline S. thermocarboxydus & $\operatorname{AT} 37^{\mathrm{T}}$ & DSM $44293^{T}$ & U94490 \\
\hline S. thermodiastaticus & ISP $5573^{T}$ & DSM $40573^{T}$ & Z68101 \\
\hline S. thermolineatus & & $\operatorname{DSM} 41451^{\mathrm{T}}$ & Z68097 \\
\hline S. thermonitrificans & ISP $5579^{\mathrm{T}}$ & DSM $40579^{\mathrm{T}}$ & Z68098 \\
\hline S. thermoviolaceus subsp. apingens & & DSM $41392^{\mathrm{T}}$ & Z68095 \\
\hline $\begin{array}{l}\text { S. thermoviolaceus subsp. } \\
\text { thermoviolaceus }\end{array}$ & ISP $5443^{\mathrm{T}}$ & DSM $40443^{\mathrm{T}}$ & Z68096 \\
\hline S. thermovulgaris & ISP $5444^{T}$ & DSM $40444^{T}$ & Z68094 \\
\hline S. (coelicolor) violaceoruber & Strain A3(2) & DSM 41007 & X60514 \\
\hline S. virginiae & ISP $5094^{\mathrm{T}}$ & IFO $3729^{T}$ & D85119 \\
\hline Streptomyces strain & TA56 & $\operatorname{DSM} 41741^{\mathrm{T}}$ & AJ000284 \\
\hline Streptomyces strain & NAR85 & DSM 41740 & AJ001434 \\
\hline
\end{tabular}

* ISP, International Streptomyces Project.

$\dagger$ ATCC, American Type Culture Collection, Rockville, MD, USA; DPDU, Istituto di Difesa delle Plante, Universita degli Studi di Udine, Udine, Italy; DSM, Deutsche Sammlung von Mikroorganismen und Zellkulturen, Braunschweig, Germany; IFO, Institute of Fermentation, Osaka, Japan; IMSNU, Institute of Molecular Microbiology, Seoul National University, Seoul, Republic of Korea; KCTC, Korean Collection of Type Cultures, Korean Research Institute of Bioscience and Biotechnology, Taejeon, Republic of Korea; NRRL, Northern Regional Research Laboratory, Agricultural Research Service, US Department of Agriculture, Peoria, IL, USA. 


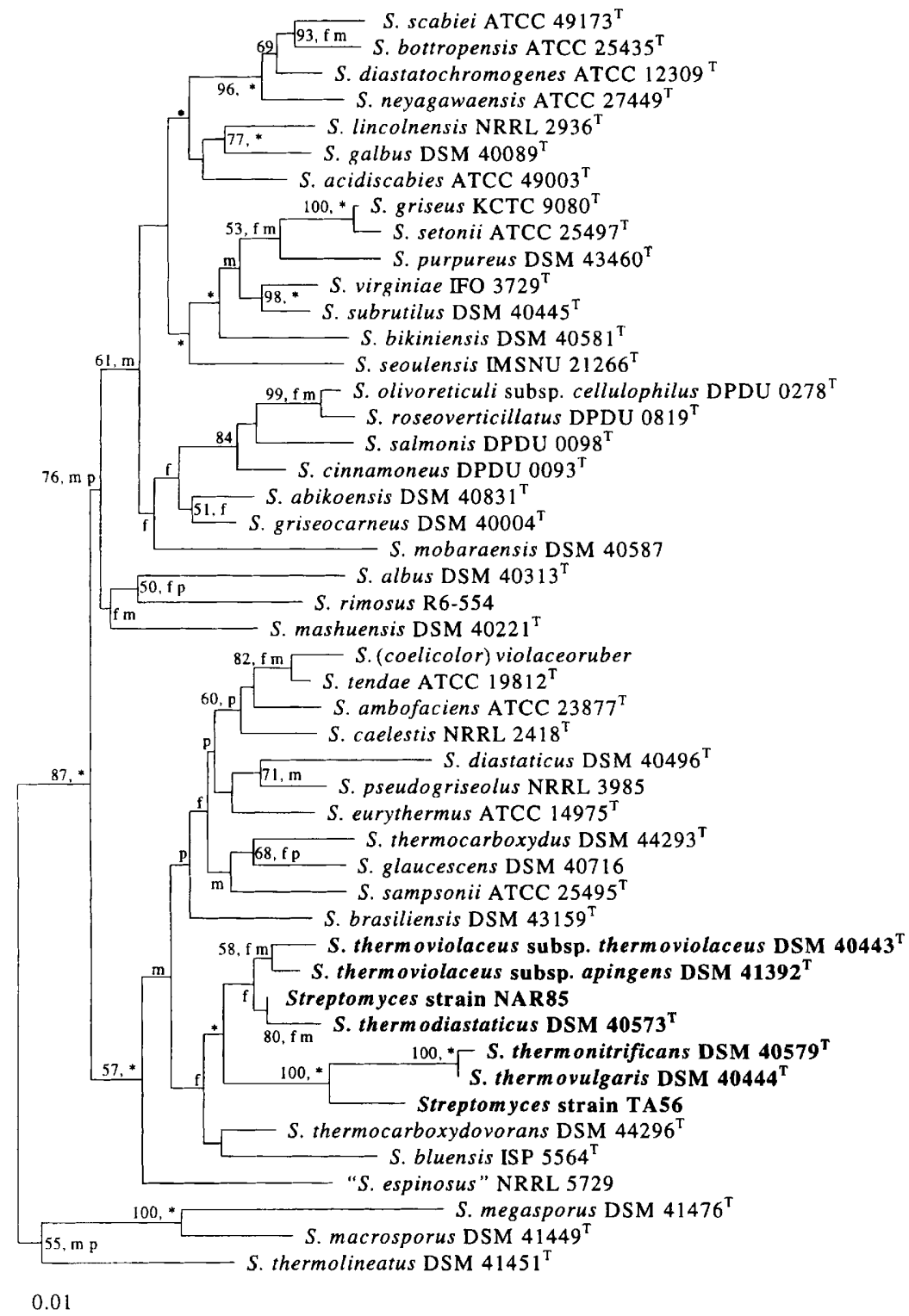

Fig. 1. Neighbour-joining tree (Saitou \& Nei, $1987)$ based on partial 16S rDNA sequences ( $<1242$ nucleotides) of 48 streptomycetes. $f$, $\mathrm{m}$ and $\mathrm{p}$ indicate branches that were also found with the least-squares (Fitch \& Margoliash, 1967), maximum-likelihood (Felsenstein, 1981) and maximum-parsimony (Kluge \& Farris, 1969) algorithms, respectively; the asterisks indicate branches that were recovered with all four methods. The numbers at the nodes indicate the level (\%) of bootstrap support based on a neighbour-joining analysis of 500 resampled data sets; only the values that were over $50 \%$ are given. The scale bar indicates 0.01 substitutions per nucleotide position. temperature, which has been used in corresponding studies (Goodfellow et al., 1987; Kim et al., 1996, 1998). Biomass for the chemical and molecular systematic analyses was obtained by growing strains in shake flasks (approx. 150 r.p.m.) for $3 \mathrm{~d}$ in tryptic soy broth and harvesting by centrifugation. The cells used for the chemical studies were washed in distilled water and freeze-dried; those required for the molecular systematic investigations were washed in $\mathrm{NaCl} /$ EDTA buffer $(0 \cdot 1 \mathrm{M}$ EDTA pH $8 \cdot 0,0 \cdot 1 \mathrm{M} \mathrm{NaCl})$ and stored at $-20^{\circ} \mathrm{C}$ until needed.

Morphology and pigmentation. The strains were examined for aerial spore mass colour and spore chain morphology following incubation on inorganic salt-starch agar for $5 \mathrm{~d}$. Soluble pigment production was detected on glucose asparagine agar (ISP medium 5, Difco; Shirling \& Gottlieb, 1966), and the production of melanin pigments on peptone yeast extract iron agar (ISP medium 6, Difco; Shirling \& Gottlieb, 1966) and tyrosine agar (ISP medium 7, Difco; Shirling \& Gottlieb, 1966). In all cases plates were incubated for $7 \mathrm{~d}$. Spore chain morphology and spore surface or- namentation of Streptomyces strains NAR85 and TA56 were examined by scanning electron microscopy, as described previously (O'Donnell et al., 1993).

Degradation and growth tests. The degradation and growth tests (Table 4) were carried out on the strains using the media and methods described by Williams et al. (1983). Inoculated plates were incubated for $7 \mathrm{~d}$ apart from some of the temperature tests. Growth at 10,15 and $20^{\circ} \mathrm{C}$ was examined after $15 \mathrm{~d}$; the remaining growth tests were read after $7 \mathrm{~d}$.

Chemotaxonomic analyses. The isomeric form of diaminopimelic acid of 11 of the strains (Table 1) was determined by TLC of whole-organism hydrolysates on cellulose acetate sheets as described by Staneck \& Roberts (1974). Menaquinones were extracted from dried biomass of $S$. thermonitrificans DSM $40579^{\mathrm{T}}, S$. thermovulgaris DSM $40444^{\mathrm{T}}$ and Streptomyces strain TA56, and purified using the preparative TLC procedure of Minnikin et al. (1984). The purified menaquinones were separated by HPLC using a Pharmacia LKB instrument fitted with a Spherisorb ODS 
Table 3. Mean levels of DNA relatedness (\%) found amongst representative thermophilic streptomycetes using the nitrocellulose filter method

The pairwise DNA relatedness values shown were obtained by averaging measurements of two sets of hybridizations. In each hybridization, one of a pair of DNA preparations was labelled.

\begin{tabular}{|c|c|c|c|c|c|c|c|}
\hline \multirow[t]{2}{*}{ Strain } & \multicolumn{7}{|c|}{ Labelled strains: } \\
\hline & $\begin{array}{l}\text { DSM } \\
\mathbf{4 0 4 4 4}^{\mathrm{T}}\end{array}$ & $\begin{array}{l}\text { DSM } \\
40579^{\mathrm{T}}\end{array}$ & TA56 & $\begin{array}{l}\text { DSM } \\
\mathbf{4 0 5 7 3}^{\text {T }}\end{array}$ & NAR85 & $\begin{array}{l}\text { DSM } \\
41392^{T}\end{array}$ & $\begin{array}{c}\text { DSM } \\
\mathbf{4 0 4 4 3}^{\mathrm{T}}\end{array}$ \\
\hline S. thermovulgaris DSM $40444^{\mathrm{T}}$ & 100 & & & & & & \\
\hline S. thermonitrificans DSM $40579^{\mathrm{T}}$ & 91 & 100 & & & & & \\
\hline Streptomyces strain TA56 & 62 & 50 & 100 & & & & \\
\hline S. thermodiastaticus DSM $40573^{\mathrm{T}}$ & 11 & 12 & 17 & 100 & & & \\
\hline Streptomyces strain NAR85 & 8 & $\mathrm{ND}$ & ND & 97 & 100 & & \\
\hline $\begin{array}{l}\text { S. thermoviolaceus subsp. apingens } \\
\text { DSM } 41392^{\mathrm{T}}\end{array}$ & 12 & $\mathrm{ND}$ & ND & 46 & 48 & 100 & \\
\hline $\begin{array}{l}\text { S. thermoviolaceus subsp. } \\
\text { thermoviolaceus } \text { DSM } 40443^{\mathrm{T}}\end{array}$ & 10 & 13 & 17 & 58 & 55 & 95 & 100 \\
\hline S. griseus ISP $5236^{\mathrm{T} *}$ & 2 & 2 & 1 & 8 & 9 & 6 & 6 \\
\hline
\end{tabular}

ND, Not determined.

* Mesophilic Streptomyces control strain.

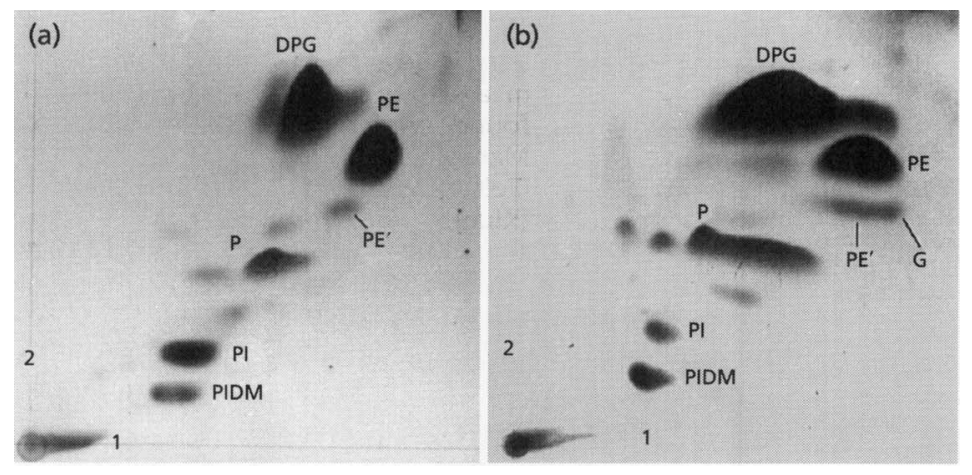

Fig. 2. Two-dimensional TLC of polar lipids of (a) S. thermovulgaris DSM $40444^{\top}$ and (b) Streptomyces strain TA56. DPG, diphosphatidylglycerol; $P E$, phosphatidylethanolamine; $\mathrm{PE}^{\prime}$, phosphatidylethanolamine derivative; PI, phosphatidylinositol; PIDM, phosphatidylinositol dimannoside; $G$, unidentified glycolipid; P, unidentified phospholipid. Numbers indicate the order of development.

column $(5 \mu \mathrm{m}$ particle size, $250 \times 4.6 \mathrm{~mm}$ i.d.; Jones Chromatography). Polar lipids extracted from these strains were examined by two-dimensional TLC and identified using published procedures (Minnikin et al., 1984).

DNA base composition. The base composition of the genomic DNA isolated from $S$. thermonitrificans DSM $40579^{\mathrm{T}}, S$. thermovulgaris DSM $40444^{\mathrm{T}}$ and Streptomyces strain TA56 was determined by using the reverse-phase HPLC method described by Tamaoka (1994) and the HPLC conditions outlined by Gerke et al. (1984). The analyses were performed on a Supelcosil LC-18S column (Supelco) with $5 \mu$ m particle size and a column dimension of $15 \mathrm{~cm} \times 4.6 \mathrm{~mm}$ i.d. Molar $\mathrm{G}+\mathrm{C}$ ratios were calculated using the methods described by Mesbah et al. (1989).

Sequencing of genes encoding 165 rRNA. Extraction of genomic DNA and PCR amplification of 16S rDNA from 11 of the strains (Table 1) were carried out as described previously (Chun \& Goodfellow, 1995). The amplified fragments were purified by gel electrophoresis and sequenced directly by using a Taq DyeDeoxy Terminator Cycle Sequencing Kit (Applied Biosystems) and previously described oligonucleotide primers (Chun \& Goodfellow, 1995). Sequencing gel electrophoresis was carried out and the nucleotide sequences automatically obtained by using an Applied Biosystems DNA sequencer (model 373A) and software provided by the manufacturer.

Phylogenetic analysis. The $16 \mathrm{~S}$ rDNA sequences were aligned manually with available streptomycete nucleotide sequences (Table 2) retrieved from the Ribosomal Database Project (Maidak et al., 1997) and EMBL/GenBank database by using the AL16S program (Chun, 1995).

Evolutionary trees were inferred with four tree-making algorithms, namely, the least-squares (Fitch \& Margoliash, 1967), maximum-likelihood (Felsenstein, 1981), maximumparsimony (Kluge \& Farris, 1969) and neighbour-joining (Saitou \& Nei, 1987) algorithms. Evolutionary distance matrices for the least-squares and neighbour-joining methods were generated as described by Jukes \& Cantor 
(1969). Phylogenetic trees based on each of the algorithms were generated by using the PHYLIP package (Felsenstein, 1993). The resultant unrooted tree topologies were evaluated in light of a bootstrap analysis (Felsenstein, 1985) of the neighbour-joining method based on 500 resamplings using the SEQBOOT and CONSENSE programs in the PHYLIP package (Felsenstein, 1993).

DNA-DNA relatedness studies. Purified DNA was prepared from all of the strains following the procedure described by Mordarski et al. (1976). The quality of the DNA preparations was checked by taking spectrophotometric readings and by agarose gel electrophoresis of the samples (Sambrook et al., 1989). DNA relatedness values between strains (Table 3) were determined in duplicated experiments using the nitrocellulose membrane filter technique (Mordarski et al., 1976; Stackebrandt et al., 1981). High-molecular-mass DNA was denatured by using the alkaline extraction method and immobilized single-stranded DNA was prepared by allowing denatured DNA solutions to filter by gravity or low vacuum through nitrocellulose membrane filters $(0 \cdot 2 \mu \mathrm{m}$ pore size, Sartorius). Filter dises $(5 \mathrm{~mm})$ loaded with about $7.5 \mu \mathrm{g}$ DNA were punched out from the nitrocellulose membranes.

DNA preparations (Table 3) were labelled with deoxy[1', $\left.2^{\prime}, 5^{\prime}-{ }^{3} \mathrm{H}\right] \mathrm{CTP}$ using a nick translation kit (Amersham). The filter disc preparations were preincubated in $1 \times$ Denhardt's solution at $60^{\circ} \mathrm{C}$ for $1-2 \mathrm{~h}$. Overnight hybridization was carried out in $200 \mu 13 \times$ SSC solution (Sambrook et al., 1989) containing 35\% (w/v) deionized formamide and approximately 50000 c.p.m. of labelled DNA at $60^{\circ} \mathrm{C}$. The concentrations of SSC and the hybridization temperature were designed to achieve optimal hybridization conditions, that is, $25^{\circ} \mathrm{C}$ below the melting temperature assuming that the mean DNA base composition of Streptomyces strains is $70 \mathrm{~mol} \% \mathrm{G}+\mathrm{C}$. After hybridization, the nitrocellulose filters were washed in $3 \times$ SSC and thoroughly dried. The amount of bound probe DNA was estimated by scintillation counting and relatedness values expressed as the percentage of probe bound (mean of duplicated hybridizations) relative to the homologous reaction.

Ribotyping. Purified high-molecular-mass DNA (approx. 2-3 $\mu$ g) was digested with BamHI, Sall and PvuII (Boehringer Mannheim) using 10 units of enzyme per $1 \mu \mathrm{g}$ of DNA in a $25 \mu \mathrm{l}$ volume reaction at $37^{\circ} \mathrm{C}$ overnight. The resultant DNA fragments were separated in $20 \mathrm{~cm}$ long agarose gels $(1 \%, \mathrm{w} / \mathrm{v} ; 5 \mathrm{~mm}$ thick $)$ at $40 \mathrm{~V}$ for $20 \mathrm{~h}$ at room temperature in $1 \times$ TBE (Tris borate/EDTA; Sambrook et al., 1989) buffer. The gels were stained for up to $30 \mathrm{~min}$ with ethidium bromide $\left(0 \cdot 5 \mu \mathrm{g} \mathrm{ml}^{-1}\right)$, photographed under UV light and transferred to a Hybond- $\mathrm{N}^{+}$nylon membrane (Amersham) by using a standard Southern blotting procedure (Sambrook et al., 1989), but omitting the depurination step. High-molecular-mass fragments $(>2 \mathrm{~kb})$ were UV-nicked for $5 \mathrm{~min}$ on a UV transilluminator prior to Southern transfer.

A $7 \cdot 2 \mathrm{~kb}$ DNA fragment containing the $16 \mathrm{~S}, 23 \mathrm{~S}$ and $5 \mathrm{~S}$ portions of the rRNA operon of Streptomyces (coelicolor) violaceoruber DSM 41007 (Zakrzewska-Czerwinska, 1989) was cloned into the SalI site of the pUC18 plasmid, propagated in Escherichia coli JM109 (Promega) and used as the probe. Digoxigenin (DIG) random primer labelling of the rDNA fragment was performed by using a commercial kit according to the manufacturer's instructions (Boehringer Mannheim, 1995).

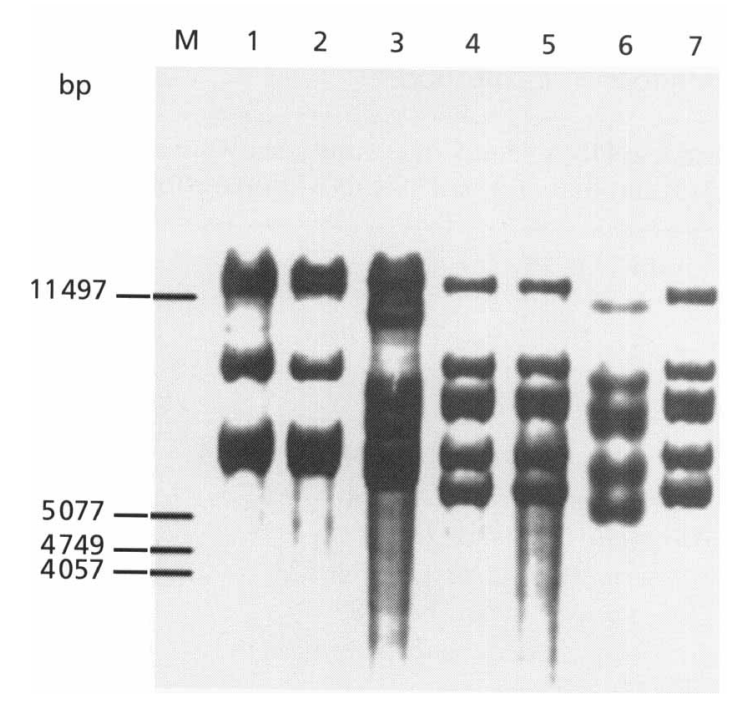

Fig. 3. Ribotyping patterns generated from BamHI genomic DNA digests hybridized with the digoxigenin-labelled rDNA probe. Lanes: 1 , S. thermovulgaris DSM 40444 ${ }^{\top} ; 2$, S. thermonitrificans DSM $40579^{\top}$; 3, Streptomyces strain TA56; 4, S. thermodiastaticus DSM $40573^{\top} ; 5$, Streptomyces strain NAR85; 6, S. thermoviolaceus subsp. thermoviolaceus DSM $40443^{\top} ; 7$, S. thermoviolaceus subsp. apingens DSM $41392^{\top} ; \mathrm{M}$, lambda DNA digested with Pstl as size marker.

\section{RESULTS AND DISCUSSION}

Numerical phenetic surveys designed to unravel the complicated taxonomic structure of the genus Streptomyces have yielded conflicting results with respect to members of some of the validly described taxa which contain thermophilic streptomycetes (Williams et al., 1983; Goodfellow et al., 1987; Kämpfer et al., 1991). In particular, the taxonomic standing of $S$. thermonitrificans Desai and Dhala 1967 is not clear as the type strain of this species has been reported to share genotypic (Ochi, 1995; Kim et al., 1996) and phenotypic (Goodfellow et al., 1987) properties in common with both $S$. thermoviolaceus (Henssen 1957) emend. Goodfellow et al. 1987 and S. thermovulgaris (Henssen 1957) emend. Goodfellow et al. 1987. Similarly, S. thermodiastaticus (Bergey et al. 1923) Waksman 1953 has many phenotypic characters in common with $S$. thermoviolaceus (Henssen 1957) emend. Goodfellow et al. 1987 , including the ability to form spores with small hemispherical warts in spiral chains (Vobis \& Henssen, 1983; Goodfellow et al., 1987). The ultrastructure of the hemispherical warts of $S$. thermoviolaceus was examined by Vobis \& Henssen (1983) who recommended that this type of spore ornamentation be designated 'tuberculate'. The close relationship between $S$. thermodiastaticus and $S$. thermoviolaceus is also evident from 16S rDNA sequencing studies (Fig. 1). DNA-DNA homology studies have been successfully used to resolve the finer taxonomic relationships between such closely related organisms, as it is generally agreed that genomic species should encompass strains which show approximately $70 \%$ or 
Table 4. Phenotypic properties of the test strains

+ , Positive, or more than $90 \%$ of strains positive in the case of the $S$. thermocarboxydovorans and $S$. thermovulgaris strains; - , negative, or more $90 \%$ of strains negative in the case of the $S$. thermocarboxydovorans and $S$. thermovulgaris strains. 1 ,

Streptomyces strain TA56; 2, S. thermocarboxydovorans; 3, S. thermodiastaticus DSM 40573 $; 4$, Streptomyces strain NAR85; 5, S. thermoviolaceus subsp. thermoviolaceus DSM 40443 $; 6$, S. thermoviolaceus subsp. apingens DSM 41392 $2^{\mathrm{T}}$;, S. thermovulgaris; 8, S. thermonitrificans DSM $40579^{\mathrm{T}}$.

\begin{tabular}{|c|c|c|c|c|c|c|c|c|}
\hline Strains... & 1 & $2^{*}$ & $3^{*}$ & 4 & 5 & $6^{*}$ & $7^{*}$ & $8^{*}$ \\
\hline $\begin{array}{l}\text { Aerial spore mass } \\
\text { colour }\end{array}$ & Grey & Grey & Grey & Grey & Grey & Grey & Grey & Grey \\
\hline $\begin{array}{l}\text { Pigmentation of } \\
\text { substrate mycelium } \dagger\end{array}$ & Not distinctive & Not distinctive & Yellowish brown & Yellowish brown & Yellow/purpleł & Yellow & Not distinctive & Not distinctive \\
\hline Spore chain§ & SP & RF & SP & SP & $\mathrm{SP}$ & SP & SP & SP \\
\hline Spore surface & Warty & Smooth & Tuberculate & Tuberculate & Tuberculate & Tuberculate & Smooth & Smooth \\
\hline Melanin production & - & - & - & - & - & - & - & - \\
\hline Nitrate reduction & + & + & - & - & - & - & + & + \\
\hline \multicolumn{9}{|l|}{ Degradation of: } \\
\hline Adenine & - & + & + & + & + & + & v & + \\
\hline Casein & + & ND & + & + & + & ND & + & + \\
\hline DNA & + & + & - & - & + & ND & + & + \\
\hline Elastin & - & + & + & + & + & + & + & + \\
\hline Gelatin & + & - & + & + & + & + & + & + \\
\hline Guanine & - & - & - & - & - & - & - & - \\
\hline Hypoxanthine & - & + & - & - & - & + & - & - \\
\hline Starch & + & + & + & + & + & + & + & + \\
\hline Testosterone & + & $\mathrm{ND}$ & + & + & -- & - & $\mathrm{v}$ & - \\
\hline L-Tyrosine & + & + & + & + & + & + & + & + \\
\hline Xanthine & - & + & - & - & - & - & - & - \\
\hline Xylan & + & + & - & - & - & - & - & - \\
\hline \multicolumn{9}{|c|}{ Growth on sole carbon sources: } \\
\hline L-Arabinose & + & - & - & - & - & + & - & - \\
\hline Fructose & + & + & + & + & + & + & + & + \\
\hline Glucose & + & + & + & + & + & + & + & + \\
\hline meso-Inositol & + & ND & + & - & + & + & + & + \\
\hline Mannitol & + & $\mathrm{ND}$ & + & + & + & + & + & + \\
\hline Raffinose & - & ND & + & + & - & - & - & - \\
\hline Rhamnose & + & ND & - & + & - & - & - & - \\
\hline Sucrose & + & + & - & - & - & + & + & + \\
\hline Xylose & + & + & + & + & + & + & + & + \\
\hline \multicolumn{9}{|l|}{ Growth at: } \\
\hline $10^{\circ} \mathrm{C}$ & - & - & - & - & - & - & - & - \\
\hline $15^{\circ} \mathrm{C}$ & - & - & - & - & - & - & - & - \\
\hline $20^{\circ} \mathrm{C}$ & - & + & - & - & + & + & - & - \\
\hline $25^{\circ} \mathrm{C}$ & + & + & + & + & + & + & + & + \\
\hline $30^{\circ} \mathrm{C}$ & + & + & + & + & + & + & + & + \\
\hline $37^{\circ} \mathrm{C}$ & + & + & + & + & + & + & + & + \\
\hline $45^{\circ} \mathrm{C}$ & + & + & + & + & + & + & + & + \\
\hline $50^{\circ} \mathrm{C}$ & + & + & + & + & + & + & + & + \\
\hline $55^{\circ} \mathrm{C}$ & + & + & + & + & + & + & + & + \\
\hline $60^{\circ} \mathrm{C}$ & - & - & - & - & - & - & - & - \\
\hline $\mathrm{pH} 6$ & + & + & + & + & + & + & + & + \\
\hline $\mathrm{pH} 10$ & + & + & - & - & - & - & + & + \\
\hline
\end{tabular}

ND, Not determined; v, variable.

* Data taken from previous studies (Shirling \& Gottlieb, 1969, 1972; Williams et al., 1983; Goodfellow et al., 1987; Sahin, 1995; Kim et al., 1998).

† Observed on oatmeal agar.

$\ddagger$ Substrate mycelium is initially yellow but becomes purple after $5 \mathrm{~d}$ due to the formation of a diffusible purple pigment.

$\S \mathrm{RF}$, rectiflexibiles; SP, spirales.

more DNA-DNA relatedness under suitable experimental conditions (Wayne et al., 1987; Stackebrandt \& Goebel, 1994; Goodfellow et al., 1997).

The DNA homology data show that $S$. thermonitrificans DSM $40579^{\mathrm{T}}$ and $S$. thermovulgaris DSM $40444^{\mathrm{T}}$ belong to a single genomic species which is readily distinguished from a corresponding taxon which encompasses $S$. thermoviolaceus subsp. apingens and $S$. thermoviolaceus subsp. thermoviolaceus (Table $3)$. The type strains of $S$. thermonitrificans and $S$. thermovulgaris share almost identical $16 \mathrm{~S}$ rDNA sequences (Kim et al., 1996), have similar ribosomal AT-L30 proteins (Ochi, 1995), have diphosphatidylglycerol, phosphatidylethanolamine, phosphatidylinositol, phosphatidylinositol dimannosides and unidentified phospholipids as major polar lipids (Fig. 2a), have octahydrogenated menaquinones with nine isoprene units as the predominant isoprenologue, and $\mathrm{G}+\mathrm{C}$-rich DNA (70 and $72 \mathrm{~mol} \%$, respectively). The identical ribotype patterns shown by these strains also serve to distinguish them from $S$. thermodiastaticus 


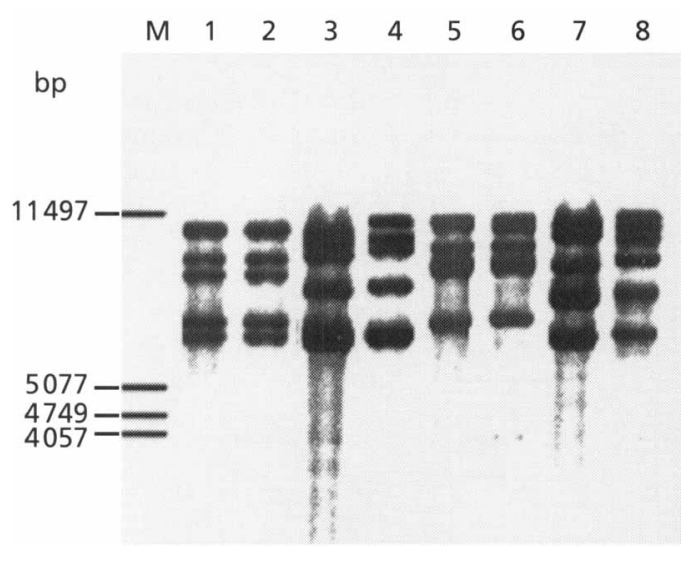

Fig. 4. Ribotyping patterns generated from Sall (lanes 1-4) and Pvull (lanes 5-8) genomic DNA digests hybridized with the digoxigenin-labelled rDNA probe. Lanes: 1 and $5, S$. thermodiastaticus DSM $40573^{\mathrm{T}} ; 2$ and 6 , Streptomyces strain NAR85; 3 and 7,5 . thermoviolaceus subsp. thermoviolaceus DSM $40443^{\top} ; 4$ and 8 , S. thermoviolaceus subsp. apingens DSM 41392 ${ }^{\top}$; M, lambda DNA digested with Pstl as size marker.

and S. thermoviolaceus (Fig. 3) and underpins the results of an early investigation where $S$. thermonitrificans DSM $40579^{\mathrm{T}}$ and $S$. thermovulgaris DSM $40444^{\mathrm{T}}$ were found to produce similar randomly amplified polymorphic DNA profiles, albeit ones which were markedly different from those generated by $S$. thermodiastaticus DSM $40573^{\mathrm{T}}$ and $S$. thermoviolaceus DSM $40443^{\mathrm{T}}$ (Kim et al., 1998). It is clear from both the present and earlier results that $S$. thermonitrificans DSM $40579^{\mathrm{T}}$ and $S$. thermovulgaris DSM $40444^{\mathrm{T}}$ are members of the same species. It is therefore proposed that $S$. thermonitrificans Desai and Dhala 1967 be recognized as a subjective synonym of S. thermovulgaris (Henssen 1957) emend. Goodfellow et al. 1987. This proposal supersedes an earlier one where it was proposed that $S$. thermonitrificans be accepted as a subjective synonym of $S$. thermoviolaceus (Goodfellow et al., 1987). It is also clear that the thermophilic alkalitolerant Streptomyces (strains A1853, A1956, NT218, TA12, TA26, TA61, TA123, TA179 and TA265) are bona fide members of $S$. thermovulgaris as they share DNA relatedness values of over $90 \%$ with labelled DNA preparations from $S$. thermovulgaris strains DSM $40444^{\mathrm{T}}$ and DSM 40579.

$16 \mathrm{~S}$ rDNA sequence data show that $S$. thermodiastaticus DSM $40573^{\mathrm{T}}$ is most closely related to $S$. thermocarboxydovorans DSM $44296^{\mathrm{T}}(99.0 \%$ nucleotide sequence similarity), $S$. thermoviolaceus subsp. apingens DSM $41392^{\mathrm{T}}(99 \cdot 1 \%), S$. thermoviolaceus subsp. thermoviolaceus DSM $40443^{\mathrm{T}}(99 \cdot 4 \%)$ and $S$. thermovulgaris DSM $40444^{\mathrm{T}}(97 \cdot 7 \%$ ) (Kim et al., 1996 , 1998). However, it is clear from the DNA relatedness data that the type strains of $S$. thermodiastaticus, $S$. thermoviolaceus and $S$. thermovulgaris belong to different genomic species (Table 3). Members of these taxa can also be distinguished from one another and from related taxa, including $S$. thermocarboxy- dovorans, using a combination of phenotypic properties (Table 4). S. thermodiastaticus DSM $40573^{\mathrm{T}}$ was also distinguished from the type strains of the two subspecies of $S$. thermoviolaceus when genomic digests prepared using $P v u I I$ and SaII restriction endonucleases were probed with the $7.2 \mathrm{~kb}$ DNA fragment from $S$. (coelicolor) violaceoruber DSM 41007 (Fig. 4). However, all three of these strains gave similar banding patterns in the corresponding experiments with $\mathrm{BamHI}$ genomic digests, though the profile for the $S$. thermoviolaceus subsp. thermoviolaceus strain showed bands with slightly lower molecular masses than those of the $S$. thermoviolaceus subsp. apingens strain; these differences may be due to deletions in the DNA near the rRNA operons (Fig. 3).

The inclusion of $S$. thermodiastaticus DSM $40573^{\mathrm{T}}$ in the Streptomyces halstedii (Williams et al., 1983) and Streptomyces rochei (Kämpfer et al., 1991) numerical phenetic clusters can be attributed to the poor growth of this strain at the incubation temperatures used $(25$ and $28^{\circ} \mathrm{C}$, respectively), and to test and sampling error (Sneath \& Johnson, 1972). Similar factors probably explain the assignment of $S$. thermoviolaceus DSM $40443^{\mathrm{T}}$ to the Streptomyces aurantiacus (Williams et al., 1983) and Streptomyces graminofaciens (Kämpfer et al., 1991) clusters. It can be concluded from the present study that $S$. thermodiastaticus (Bergey et al. 1923) Waksman 1953 and S. thermoviolaceus (Henssen 1957) emend. Goodfellow et al. 1987 continue to merit recognition as validly described species.

All of the thermophilic alkalitolerant isolates (strains A1853, A1956, NT218, TA12, TA26, TA56, TA61, TA123, TA179 and TA265) share a number of phenotypic properties which are consistent with their classification in the genus Streptomyces (Williams et al., 1989; Manfio et al., 1995). They all formed an extensively branched substrate mycelium, aerial hyphae which differentiated into long chains of spores, and gave whole-organism hydrolysates that were rich in LL-diaminopimelic acid. It is evident from the DNA homology studies that all but one of the thermophilic alkalitolerant representatives of the numerical phenetic clusters recognized by Sahin (1995), namely, Streptomyces strain TA56, showed $90 \%$ or more DNA relatedness with reference DNA prepared from $S$. thermovulgaris DSM 40444 ${ }^{\mathrm{T}}$ (Table 3). These organisms also formed a grey aerial spore mass, lacked distinct substrate mycelium pigments, formed spores in spiral chains and were melanin-negative; all of these properties are typical of bona fide members of the taxon S. thermovulgaris (Goodfellow et al., 1987; Sahin, 1995). In addition, all of these strains gave the same ribotype pattern as $S$. thermovulgaris DSM $40444^{\mathrm{T}}$ when Bam HI genomic digests were hybridized with the rDNA probe (Fig. 3).

Streptomyces strain TA56 formed a distinct singlemembered cluster (Sahin, 1995), albeit one related to phena shown in this investigation to accommodate $S$. thermovulgaris strains. The 16S rDNA (Fig. 1) and 


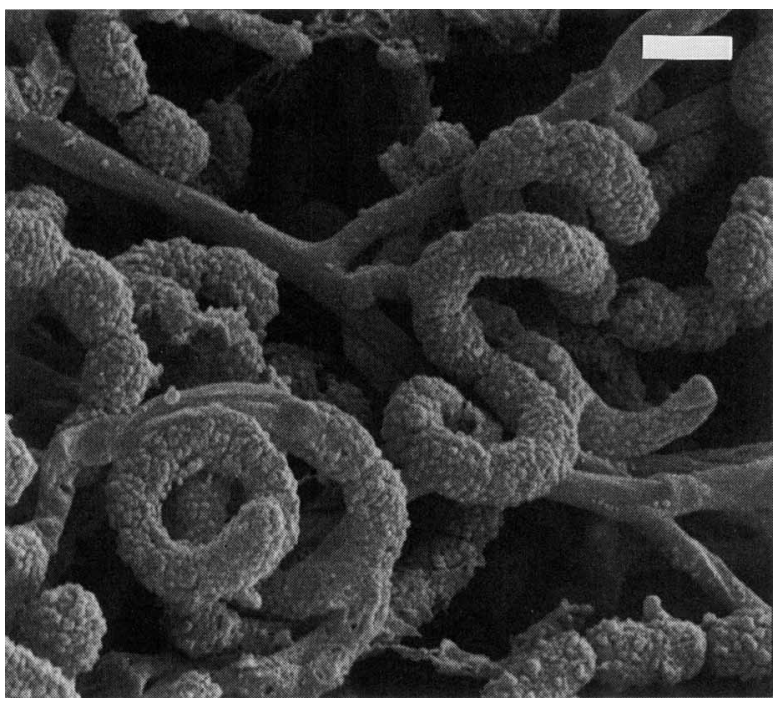

Fig. 5. Scanning electron micrograph showing coiled spore chains with warty surface of Streptomyces strain TA56. The organism was grown on inorganic salt-starch agar (ISP medium 4) at $45^{\circ} \mathrm{C}$ for $5 \mathrm{~d}$. Bar, $1 \mu \mathrm{m}$.

DNA relatedness (Table 3) data are in good agreement with the results of the numerical taxonomic study. Streptomyces strain TA56 showed its closest 16S rDNA sequence similarity with $S$. thermovulgaris DSM $40444^{\mathrm{T}}(98.9 \%$ or 1271 out of 1285 nucleotides shared) and a corresponding high DNA relatedness value (Table 3), though one well below the $70 \%$ cut-off point used to assign strains to single genomic species (Wayne et al., 1987; Goodfellow et al., 1997). A number of phenotypic features can also be weighted to differentiate Streptomyces strain TA56 from $S$. thermovulgaris strains (Table 4), not least the ability of the former to form warty-surfaced (Fig. 5) as opposed to smooth spores. The two strains can also be distinguished by their polar lipid patterns as Streptomyces strain TA56 produced an unidentified glycolipid ( $\alpha$ naphthol- and periodate/Schiff-positive) which comigrated with a phosphatidylethanolamine derivative spot (Fig. 2a, b). Streptomyces strain TA56 and $S$. thermovulgaris DSM $40444^{\mathrm{T}}$ gave different ribotype patterns when high-molecular-mass DNA from these organisms was digested with $B a m \mathrm{HI}$ and treated with the rDNA probe prepared from $S$. (coelicolor) violaceoruber DSM 41007 (Fig. 3). It is interesting that strain TA56 has octahydrogenated menaquinone with nine isoprene units as the predominant isoprenologue like $S$. thermovulgaris DSM $40444^{\mathrm{T}}$ and DSM 40579.

It is clear from both the genotypic and phenotypic data that Streptomyces strain TA56 is related to, but distinct from, $S$. thermovulgaris. It can also be differentiated from $S$. thermoautotrophicus for, unlike the latter, it is not an obligate chemolithoautotroph and does not grow at $65^{\circ} \mathrm{C}$ (Gadkari et al., 1990). Accordingly, the new species Streptomyces thermoalcalitolerans is proposed for Streptomyces strain TA56.

\section{Description of Streptomyces thermoalcalitolerans sp.} nov.

Streptomyces thermoalcalitolerans (ther.mo.al.ca.li.to'le.rans. Gr. n. therme heat; N.L. n. alcali from arabic al end; galiy soda ash; L. pres. part. tolerans tolerating, enduring; M.L. part. adj. thermoalcalitolerans thermophilic alkali-tolerating).

The description is based on data taken from this and an earlier study (Sahin, 1995). Aerobic, Gram-positive, thermophilic actinomycete with extensively branched substrate and aerial hyphae. Spiral chains of warty surfaced spores are borne on aerial hyphae. The aerial spore mass is grey; neither distinctive substrate mycelium colours nor diffusible pigments are formed. Melanin pigments are not produced on peptone iron agar. Casein, DNA, gelatin, starch, testosterone, Ltyrosine and xylan are degraded, but not adenine, arbutin, elastin, guanine, hypoxanthine or xanthine. Adonitol, L-arabinose, arabitol, D-cellobiose, D-fructose, D-galactose, D-glucose, meso-inositol, $\alpha$-lactose, D-mannitol, D-mannose, D-melezitose hydrate, melibiose, $\alpha$-L-rhamnose, D-ribose, D-sorbitol, sucrose, Dtrehalose, D-turanose, xylitol and D-xylose are used as sole carbon sources for energy and growth, but Draffinose is not. Growth occurs between 25 and $55^{\circ} \mathrm{C}$, from $\mathrm{pH} 6.0$ to 11.5 , and in the presence of ampicillin $\left(8 \mu \mathrm{g} \mathrm{ml}^{-1}\right)$, bacitracin $\left(16 \mu \mathrm{g} \mathrm{ml}^{-1}\right)$, oleandomycin phosphate $\left(16 \mu \mathrm{g} \mathrm{ml}^{-1}\right)$, penicillin $\mathrm{G}$ (15 international units), rifampicin $\left(16 \mu \mathrm{g} \mathrm{ml}^{-1}\right)$, streptomycin sulphate $\left(4 \mu \mathrm{g} \mathrm{ml}^{-1}\right)$, tetracycline hydrochloride $\left(16 \mu \mathrm{g} \mathrm{ml}^{-1}\right)$ and tunicamycin $\left(10 \mu \mathrm{g} \mathrm{m}^{-1}\right)$. In contrast, growth is inhibited in the presence of gentamicin sulphate $(8 \mu \mathrm{g}$ $\left.\mathrm{ml}^{-1}\right)$, lincomycin hydrochloride $\left(32 \mu \mathrm{g} \mathrm{ml}^{-1}\right)$, neomycin sulphate $\left(8 \mu \mathrm{g} \mathrm{ml}^{-1}\right)$, novobiocin $\left(4 \mu \mathrm{g} \mathrm{ml}^{-1}\right)$, oleandomycin phosphate $\left(32 \mu \mathrm{g} \mathrm{ml}^{-1}\right)$, polymyxin B phosphate $\left(32 \mu \mathrm{g} \mathrm{ml}^{-1}\right)$, rifampicin $\left(32 \mu \mathrm{g} \mathrm{ml}^{-1}\right)$, streptomycin sulphate $\left(16 \mu \mathrm{g} \mathrm{ml} l^{-1}\right)$, tetracycline hydrochloride $\left(32 \mu \mathrm{g} \mathrm{m} l^{-1}\right)$, tobramycin sulphate $(32 \mu \mathrm{g}$ $\left.\mathrm{ml}^{-1}\right)$ and vancomycin hydrochloride $\left(16 \mu \mathrm{g} \mathrm{ml}^{-1}\right)$. The DNA base composition of the organism is $73 \mathrm{~mol} \% \mathrm{G}+\mathrm{C}$. Isolated from tropical garden soil collected by M. Goodfellow in 1991 from Yogyakarta, Central Java, Indonesia. The type strain, TA56 (= DSM 41741) is deposited in the DSMZ, Braunschweig, Germany.

\section{Neutrophilic isolate}

The only neutrophilic thermophilic isolate included in this study, Streptomyces strain NAR85, formed a single-membered cluster in the numerical phenetic survey of Sahin (1995). This taxon formed an aggregate group together with $S$. thermodiastaticus DSM $40573^{\mathrm{T}}$ and $S$. thermoviolaceus DSM $40443^{\mathrm{T}}$. The close association with $S$. thermodiastaticus was underpinned by the results of the DNA homology studies as strain NAR85 showed $97 \%$ DNA relatedness with labelled DNA prepared from $S$. thermodiastaticus DSM $40573^{\mathrm{T}}$. This assignment is also supported by phenotypic (Table 4), ribotyping (Figs 3, 4) and 16S rDNA 
sequence data. The sequence data show that strain NAR85 is closely related to $S$. thermodiastaticus DSM $40573^{\mathrm{T}}(99 \cdot 5 \%$ nucleotide sequence similarity) and $S$. thermoviolaceus DSM $40443^{\mathrm{T}}(99 \cdot 4 \%)$. It is clear from both the genotypic and phenotypic data that strain NAR85 belongs to the species $S$. thermodiastaticus. Streptomyces strain NAR85 has been deposited in the DSMZ, Braunschweig, Germany, under the accession number DSM 41740.

\section{ACKNOWLEDGEMENTS}

Bongcheol Kim was supported by an Overseas Research Studentship Award and Nevzat Sahin by a scholarship from the Government of Turkey. The authors are also indebted to Professor R. M. Kroppenstedt for providing cultures and to M. Guzik and B. Lis for assistance with the DNA hybridization experiments.

\section{REFERENCES}

Agre, N. S. (1983). Genera Streptomyces, Streptoverticillium and Chainia. In A Guide for the Determination of Actinomycetes, pp. 52-71. Edited by T. F. Gause, T. P. Preobrazhenskaya, M. A. Sveshnikova, L. P. Terekhova \& T. S. Maksimova. Moscow: Nauka (in Russian).

Bergey, D. H., Harrison, F. C., Breed, R. S., Hammer, B. W. \& Huntoon, F. M. (1923). Bergey's Manual of Determinative Bacteriology, 1st edn. Baltimore: Williams \& Wilkins.

Chun, J. (1995). Computer-assisted classification and identification of actinomycetes. PhD thesis, University of Newcastle upon Tyne.

Chun, J. \& Goodfellow, M. (1995). A phylogenetic analysis of the genus Nocardia with 16S rRNA gene sequences. Int $J$ Syst Bacteriol 45, 240-245.

Chun, J., Youn, H.-D., Yim, Y.-I., Lee, H., Kim, M. Y., Hah, Y. C. \& Kang, S.-O. (1997). Streptomyces seoulensis sp. nov. Int J Syst Bacteriol 47, 492-498.

Craveri, R. \& Pagani, H. (1962). Thermophilic micro-organisms among actinomycetes in the soil. Ann Microbiol 12, 115-130.

Desai, A. J. \& Dhala, S. A. (1967). Streptomyces thermonitrificans sp. n., a thermophilic streptomycete. Antonie Leeuwenhoek 33, 137-144.

Felsenstein, J. (1981). Evolutionary tree from DNA sequences: a maximum likelihood approach. J Mol Evol 17, 368-376.

Felsenstein, J. (1985). Confidence limits on phylogeny: an approach using the bootstrap. Evolution 39, 783-791.

Felsenstein, J. (1993). PHYLIP (Phylogenetic Inference Package), version 3.5c. Department of Genetics, University of Washington, Seattle, USA.

Fitch, W. M. \& Margoliash, E. (1967). Construction of phylogenetic trees: a method based on mutation distances as estimated from cytochrome $c$ sequences is of general applicability. Science 155, 279-284.

Gadkari, D., Schricker, K., Acker, G., Kroppenstedt, R. M. \& Meyer, O. (1990). Streptomyces thermoautotrophicus sp. nov., a thermophilic $\mathrm{CO}$ - and $\mathrm{H}_{2}$-oxidizing obligate chemolithotroph. Appl Environ Microbiol 56, 3727-3734.

Gerke, C. W., McCune, R. A., Gama-Sosa, M. A., Ehrlich, M. \& Kuo, K. C. (1984). Quantitative reversed-phase high-performance liquid chromatography of major and modified nucleosides in DNA. J Chromatogr 301, 199-219.
Gilbert, R. (1904). Über Actinomyces thermophilus und andere Actinomyceten. Z Hyg Infektionskr 47, 383-406.

Goodfellow, M., Lacey, J. \& Todd, C. (1987). Numerical classification of thermophilic streptomycetes. $J$ Gen Microbiol 133, 3135-3149.

Goodfellow, M., Manfio, G. P. \& Chun, J. (1997). Towards a practical species concept for cultivatable bacteria. In Species: the Units of Biodiversity, pp. 25-59. Edited by M. F. Claridge, H. A. Dawah \& M. R. Wilson. London: Chapman \& Hall.

Hain, T., Ward-Rainey, N., Kroppenstedt, R. M., Stackebrandt, E. \& Rainey, F. A. (1997). Discrimination of Streptomyces albidoflavus strains based on the size and number of $16 \mathrm{~S}-23 \mathrm{~S}$ ribosomal DNA intergenic spacers. Int J Syst Bacteriol 47, 202-206.

Hatano, K., Nishii, T. \& Mordarska, H. (1997). Streptomyces spitzbergensis Wieczorek et al. 1993 is a later subjective synonym of Streptomyces baldacii (Farina and Locci 1966) Witt and Stackebrandt 1991. Int J Syst Bacteriol 47, 573-574.

Henssen, A. (1957). Über die Bedeutung der thermophilen Mikroorganismen für der Zersetzung des Stallmistes. Arch Mikrobiol 27, 63-81.

Jukes, T. H. \& Cantor, C. R. (1969). Evolution of protein molecules. In Mammalian Protein Metabolism, vol. 3, pp. 21-132. Edited by H. N. Munro. New York: Academic Press.

Kämpfer, P., Kroppenstedt, R. M. \& Dott, W. (1991). A numerical classification of the genera Streptomyces and Streptoverticillium using miniaturized physiological tests. J Gen Microbiol 137, 1831-1891.

Kim, D., Chun, J., Sahin, N., Hah, Y.-C. \& Goodfellow, M. (1996). Analysis of thermophilic clades within the genus Streptomyces by $16 \mathrm{~S}$ ribosomal DNA sequence comparisons. Int $J$ Syst Bacteriol 46, 581-587.

Kim, S. B., Falconer, C., Williams, E. \& Goodfellow, M. (1998). Streptomyces thermocarboxydovorans $\mathrm{sp}$. nov. and Streptomyces thermocarboxydus sp. nov., two moderately thermophilic carboxydotrophic species from soil. Int $J$ Syst Bacteriol 48, $59-68$.

Kluge, A. G. \& Farris, F. S. (1969). Quantitative phyletics and the evolution of anurans. Syst Zool 18, 1-32.

Krassilnikov, N. A., Agre, N. S., Dorokhova, L. A. \& Sokolov, A. A. (1968). Three new species of thermophilic actinomycetes. Mikrobiologiya 37, 75-83 (in Russian).

Kudrina, E. S. \& Maximova, T. S. (1963). Some species of thermophilic Actinomyces from soils of China and their antibiotic properties. Mikrobiologiva 32, 623-631 (in Russian). Labeda, D. P. (1993). DNA relatedness among strains of the Streptomyces lavendulae phenotypic cluster group. Int $J$ Syst Bacteriol 43, 822-825.

Labeda, D. P. (1996). DNA relatedness among verticil-forming Streptomyces species (formerly Streptoverticillium species). Int J Syst Bacteriol 46, 699-703.

Labeda, D. P., Lechevalier, M. P. \& Testa, R. T. (1997). Streptomyces stramineus sp. nov, a new species of the verticillate streptomycetes. Int $J$ Syst Bacteriol 47, 747-753.

Maidak, B. L., Olsen, G. J., Larsen, N., Overbeek, R., McCaughey, M. J. \& Woese, C. R. (1997). The Ribosomal Database Project (RDP). Nucleic Acids Res 25, 109-111.

Manfio, G. P., Zakrezewska-Czerwinska, J., Atalan, E. \& Goodfellow, M. (1995). Towards minimal standards for the description of Streptomyces species. Biotechnologia 7-8, 242-253. Mesbah, M., Premachandran, U. \& Whitman, W. B. (1989). Precise 
measurement of the $\mathrm{G}+\mathrm{C}$ content of deoxyribonucleic acid by high-performance liquid chromatography. Int J Syst Bacteriol 39, 159-167.

Minnikin, D. E., O'Donnell, A. G., Goodfellow, M., Alderson, G., Athayle, M., Schaal, A. \& Parlett, J. H. (1984). An integrated procedure for the extraction of bacterial isoprenoid quinones and polar lipids. J Microbiol Methods 2, 233-241.

Mordarski, M., Szyba, K., Pulverer, G. \& Goodfellow, M. (1976). Deoxyribonucleic acid reassociation in the classification of the 'rhodochrous' complex and allied taxa. J Gen Microbiol 94, 235-245.

Ochi, K. (1995). A taxonomic study of the genus Streptomyces by analysis of ribosomal protein AT-L30. Int J Syst Bacteriol 45, 507-514.

O'Donnell, A. G., Falconer, C., Goodfellow, M., Ward, A. C. \& Williams, E. (1993). Biosystematics and diversity amongst novel carboxydotrophic actinomycetes. Antonie Leeuwenhoek 64, 325-340.

Pridham, T. G. (1970). New names and new combinations in the order Actinomycetales Buchanan 1917. Tech Bull ARS USDA 1424, 1-55.

Sahin, N. (1995). Selective isolation, characterisation and classification of novel thermotolerant streptomycetes. $\mathrm{PhD}$ thesis, University of Newcastle upon Tyne.

Saitou, N. \& Nei, M. (1987). The neighbor-joining method: a new method for reconstructing phylogenetic trees. Mol Biol Evol 4, 406-425.

Sambrook, J., Fritsch, E. F. \& Maniatis, T. (1989). Molecular Cloning : a Laboratory Manual, 2nd edn. Cold Spring Harbor, NY : Cold Spring Harbor Laboratory.

Shirling, E. B. \& Gottlieb, D. (1966). Methods for characterization of Streptomyces species. Int J Syst Bacteriol 16, 313-340.

Shirling, E. B. \& Gottlieb, D. (1969). Cooperative description of type cultures of Streptomyces. IV. Species descriptions from the second, third and fourth studies. Int $J$ Syst Bacteriol 19, 391-512.

Shirling, E. B. \& Gottlieb, D. (1972). Cooperative description of type strains of Streptomyces. V. Additional descriptions. Int $J$ Syst Bacteriol 22, 265-394.

Sneath, P. H. A. \& Johnson, R. (1972). The influence on numerical taxonomic similarities of error in microbiological tests. $J$ Gen Microbiol 72, 377-392.
Stackebrandt, E. \& Goebel, B. M. (1994). A place for DNA-DNA reassociation and $16 \mathrm{~S}$ rRNA sequence analysis in the present species definition in bacteriology. Int $J$ Syst Bacteriol 44, 846-849.

Stackebrandt, E., Wunner-Füssl, B., Fowler, V. J. \& Schleifer, K.-H. (1981). Deoxyribonucleic acid homologies and ribosomal ribonucleic acid similarities among sporeforming members of the order Actinomycetales. Int J Syst Bacteriol 31, 420-431.

Staneck, J. L. \& Roberts, G. D. (1974). Simplified approach to identification of aerobic actinomycetes by thin-layer chromatography. Appl Microbiol 28, 226-231.

Tamaoka, J. (1994). Determination of DNA base composition. In Chemical Methods in Prokaryotic Systematics, pp. 463-470. Edited by M. Goodfellow \& A. G. O'Donnell. Chichester: Wiley.

Vobis, G. \& Henssen, A. (1983). Ultrastructure of tuberculate spores in Streptomyces thermoviolaceus. Arch Microbiol 134, 295-298.

Waksman, S. A. (1953). Description of species of Streptomyces. In Guide to the Classification and Identification of Actinomycetes and their Antibiotics, p. 102. Edited by S. A. Waksman \& H. A. Lechevalier. Baltimore: Williams \& Wilkins.

Waksman, S. A. \& Henrici, A. T. (1948). Family III Streptomycetaceae Waksman and Henrici. In Bergey's Manual of Systematic Bacteriology, 6th edn, pp. 929-980. Edited by R. S. Breed, E. G. D. Murray \& P. Hitchens. Baltimore: Williams \& Wilkins.

Wayne, L. G., Brenner, D. J., Colwell, R. R. \& 9 other authors (1987). Report of the ad hoc committee on reconciliation of approaches to bacterial systematics. Int J Syst Bacteriol 37, 463-464.

Williams, S.T., Goodfellow, M., Alderson, G., Wellington, E. M. H., Sneath, P. H. A. \& Sackin, M. J. (1983). Numerical classification of Streptomyces and related genera. $J$ Gen Microbiol 129, 1743-1813.

Williams, S. T., Goodfellow, M. \& Alderson, G. (1989). Genus Streptomyces Waksman and Henrici 1943, 339 ${ }^{\wedge \mathrm{L}}$. In Bergey's Manual of Systematic Bacteriology, vol. 4, pp. 2452-2492. Edited by S. T. Williams, M. E. Sharpe \& J. G. Holt. Baltimore: Williams \& Wilkins.

Zakrzewska-Czerwinska, J. (1989). Organization of the ribosomal RNA genes in Streptomyces strains. PhD thesis, Ludwik Hirszfeld Institute, Wroclaw, Poland. 